\title{
Crystal structures and conformers of $\mathrm{CyMe}_{4}-\mathrm{BTBP}$
}

Krzysztof Lyczko, Slawomir Ostrowski

\begin{abstract}
The crystal structure of new conformation of the CyMe $\mathrm{M}_{4}$-BTBP ligand (ttc) has been presented. The $t t t$ conformer of this compound in a form of THF solvate has been also crystallized. The geometries of six possible conformations $\left(t t t, t t c, t c t, t c c, c t c\right.$ and $c c c$ ) of the $\mathrm{CyMe}_{4}$-BTBP ligand have been modeled in the gas phase and in solutions ( $\mathrm{MeOH}$ and $\mathrm{H}_{2} \mathrm{O}$ ) by DFT calculations using B3LYP/6-31G $(\mathrm{d}, \mathrm{p})$ method. According to the calculations, in the three different media the conformers with trans orientation of the $\mathrm{N}$ atoms in the bipyridyl moiety are the most stable.
\end{abstract}

Key words: conformers $\bullet$ crystal structure $\bullet$ CyMe $\mathrm{CHTBP}_{4}$ - DFT calculations

K. Lyczko ${ }^{\bowtie}$, S. Ostrowski

Institute of Nuclear Chemistry and Technology,

16 Dorodna Str., 03-195 Warsaw, Poland,

Tel.: +48 22504 1252, Fax: +48 22811 1917,

E-mail: k.lyczko@ichtj.waw.pl

Received: 17 June 2015

Accepted: 5 September 2015

\section{Introduction}

Triazinylpyridine N-donor ligands have been recently extensively studied as convenient substances in extraction processes for the separation of actinides (III) from lanthanides(III) [1-3]. Among them the 6,6'-bis (5,5,8,8-tetramethyl-5,6,7,8-tetrahydrobenzo-1,2,4-triazin-3-yl)-2,2'-bipyridine compound, known as $\mathrm{CyMe}_{4}-\mathrm{BTBP}$, is one of the most promising agent. This compound acts as tetradentate chelating ligand to the metal ions. The crystal structure of $\mathrm{CyMe}_{4}$-BTBP in the form of methanol solvate was reported a few years ago [1]. Besides this ligand, among compounds of BTBP type, only C2-BTBP is available in the Cambridge Structural Database [1]. The crystal structures of the complexes of $\mathrm{CyMe}_{4}$-BTBP with some metal cations (i.e. $\mathrm{Pr}^{3+}$ $\mathrm{Eu}^{3+}, \mathrm{Tb}^{3+}$ and $\mathrm{Pb}^{2+}$ ) have been presented recently [3-6]. In addition, some quantum mechanical calculations on the geometry of BTBP ligands and their metal complexes have also been performed $[1,7]$. Structural studies on this type of heterocyclic ligands and their complexes are still interesting because they can help to understand the processes of metals complexation and separation.

In this work the new crystal structures for two conformers of $\mathrm{CyMe}_{4}$-BTBP have been shown. In addition, the calculations on the geometries of six conformers of the ligand discussed were carried out. 


\section{Experimental and calculation details}

\section{Chemicals}

The $\mathrm{CyMe}_{4}$-BTBP compound was synthesized according to the published method [1]. All other chemicals were used as purchased from commercial sources.

\section{Crystallization}

A small portions of $\mathrm{CyMe}_{4}$-BTBP (about $5 \mathrm{mg}$ ) were recrystallized from acetonitrile, methanol, ethanol and tetrahydrofuran solutions $(2 \mathrm{~mL}$ each $)$, giving yellow crystals after slow evaporation of solvents at room temperature within a few weeks.

\section{X-ray crystallographic analysis and data collection}

Selected crystallographic parameters and refinement details for both conformers of $\mathrm{CyMe}_{4}$-BTBP are summarized in Table 1 . X-ray diffraction data were collected at $100 \mathrm{~K}$ on an Agilent Technologies SuperNova (dual source) diffractometer equipped with EOS CCD detector. Suitable crystals of both forms were mounted within a nylon loop by means of Paratone-N cryoprotectant oil. The mirror-monochromated $\mathrm{CuK} \alpha$ radiation $(\lambda=1.54184 \AA)$ from a micro-focus Nova X-ray source was used for measurements. Data collection, data reduction and multi-scan absorption corrections were performed using CrysAlis PRO software. The structures were solved by direct methods and refined by full matrix least-squares method on $\mathrm{F}^{2}$ data. All non-hydrogen atoms were refined with anisotropic atomic displacement parameters. Hydrogen atoms bonded to carbon atoms were inserted into calculated positions with isotropic factors using riding model. The $\mathrm{CyMe}_{4}$-BTBP ligand in structure 2 (see Table 1 ) exhibits a partial disorder in one tetramethylcyclohexane end of the molecule, with the refined ratio of two components being $0.68(1): 0.32(1)$. There is also a strong disorder of the THF part in 2 showing two possible positions of that molecule with the occupancy rate refined to $0.58(1)$. All calculations were performed with the SHELXTL program package [8]. SHELXTL and MERCURY [9] programs were applied to prepare the crystal graphics.

The crystallographic data for this paper are deposited at the Cambridge Crystallographic Data Center (CCDC-1403274 (for 1) and -1403275 (for 2)). These data can be obtained free of charge via www.ccdc.cam.ac.uk/data_request/cif.

\section{Computational methodology}

The calculations were performed using the Gaussian program [10]. Geometry optimization for the six

Table 1. Crystallographic data and structure refinement parameters for two conformers of CyMe $\mathrm{CH}_{4}$-BRP

\begin{tabular}{|c|c|c|}
\hline Compound & $\begin{array}{c}\mathrm{CyMe}_{4}-\mathrm{BTBP} \\
(\mathbf{1})\end{array}$ & $\begin{array}{c}\mathrm{CyMe}_{4}-\mathrm{BTBP} \cdot \mathrm{THF} \\
\text { (2) }\end{array}$ \\
\hline Empirical formula & $\mathrm{C}_{32} \mathrm{H}_{38} \mathrm{~N}_{8}$ & $\mathrm{C}_{36} \mathrm{H}_{44} \mathrm{~N}_{8} \mathrm{O}$ \\
\hline Formula weight & 534.70 & 604.79 \\
\hline Temperature $[\mathrm{K}]$ & $100(2)$ & $100(2)$ \\
\hline$\lambda[\mathrm{CuK \alpha}][\AA]$ & 1.54184 & 1.54184 \\
\hline Crystal system & Triclinic & Monoclinic \\
\hline Space group & $P \overline{1}$ & $P 2_{1} / n$ \\
\hline \multicolumn{3}{|l|}{ Unit cell dimensions: } \\
\hline$a[\AA ̊]$ & $10.1131(2)$ & $12.06128(10)$ \\
\hline$b[\AA]$ & $11.9272(3)$ & $14.64799(13)$ \\
\hline$c[\AA]$ & $12.0979(3)$ & $18.99678(18)$ \\
\hline$\alpha\left[^{\circ}\right]$ & $80.7933(18)$ & 90.00 \\
\hline$\beta\left[^{\circ}\right]$ & $86.2899(17)$ & $99.1300(8)$ \\
\hline$\gamma\left[{ }^{\circ}\right]$ & $87.2089(17)$ & 90.00 \\
\hline Volume $[\AA]$ & $1436.35(5)$ & $3356.22(5)$ \\
\hline$Z$ & 2 & 4 \\
\hline Calculated density, $\mathrm{D}_{\mathrm{c}}\left[\mathrm{g} \cdot \mathrm{cm}^{-3}\right]$ & 1.236 & 1.197 \\
\hline Absorption coefficient, $\mu\left[\mathrm{mm}^{-1}\right]$ & 0.597 & 0.590 \\
\hline$F(000)$ & 572 & 1296 \\
\hline Crystal size $[\mathrm{mm}]$ & $0.22 \times 0.18 \times 0.10$ & $0.24 \times 0.12 \times 0.10$ \\
\hline Absorption correction & Multi-scan & Multi-scan \\
\hline Transmission, $T_{\min } / T_{\max }$ & $0.6001 / 1.0000$ & $0.79275 / 1.0000$ \\
\hline Reflections collected & 79702 & 56849 \\
\hline Independent reflections & 5239 & 6027 \\
\hline $\mathrm{R}_{\mathrm{int}}$ & 0.0449 & 0.0280 \\
\hline Data/restraints/parameters & $5239 / 0 / 369$ & $6027 / 0 / 471$ \\
\hline & $\mathrm{R}_{1}=0.0348$ & $\mathrm{R}_{1}=0.0525$ \\
\hline Final $\mathrm{R}$ indices $[I>2 \sigma(I)]$ & $w \mathrm{R}_{2}=0.0946$ & $w \mathrm{R}_{2}=0.1381$ \\
\hline GOF $\left(\mathrm{F}^{2}\right)$ & 1.013 & 1.045 \\
\hline Largest difference peak/hole $\left[\mathrm{e} \cdot \AA^{-3}\right]$ & $0.273 /-0.201$ & $0.637 /-0.500$ \\
\hline
\end{tabular}


Table 2. Selected bond lengths, distances and torsion angles for the CyMe $\mathrm{CHTBP}_{4}$ conformers on the basis of calculated (for $\mathrm{MeOH}$ solutions) and experimental molecular structure (for all conformers the same labelling of atoms as in Figs. 1 and 2 were used)

\begin{tabular}{|c|c|c|c|c|c|c|c|c|}
\hline & $\begin{array}{c}t t t \\
\text { Calc. }\end{array}$ & $\begin{array}{c}t t t \\
\text { Exp. }\end{array}$ & $\begin{array}{c}t t c \\
\text { Calc. }\end{array}$ & $\begin{array}{c}t t c \\
\text { Exp. }\end{array}$ & $\begin{array}{c}c t c \\
\text { Calc. }\end{array}$ & $\begin{array}{c}\text { tct } \\
\text { Calc. }\end{array}$ & $\begin{array}{c}t c c \\
\text { Calc. }\end{array}$ & $\begin{array}{c}c c c \\
\text { Calc. }\end{array}$ \\
\hline \multicolumn{9}{|l|}{ Bond lengths } \\
\hline N1-C5 & 1.341 & $1.344(2)$ & 1.341 & $1.339(1)$ & 1.340 & 1.342 & 1.341 & 1.331 \\
\hline $\mathrm{N} 2-\mathrm{C} 6$ & 1.341 & $1.342(2)$ & 1.340 & $1.340(1)$ & 1.340 & 1.342 & 1.341 & 1.341 \\
\hline C1-C6 & 1.493 & $1.487(2)$ & 1.492 & $1.494(1)$ & 1.493 & 1.496 & 1.496 & 1.496 \\
\hline N5-N7 & 1.328 & $1.339(2)$ & 1.328 & $1.335(1)$ & 1.331 & 1.328 & 1.328 & 1.331 \\
\hline N6-N8 & 1.328 & $1.339(2)$ & 1.330 & $1.338(1)$ & 1.331 & 1.329 & 1.331 & 1.331 \\
\hline \multicolumn{9}{|l|}{ Distances } \\
\hline $\mathrm{N} 1 \cdots \mathrm{N} 2$ & 3.610 & $3.599(2)$ & 3.608 & $3.598(1)$ & 3.607 & 2.827 & 2.795 & 2.806 \\
\hline $\mathrm{N} 1 \cdots \mathrm{N} 3$ & 2.756 & $2.761(2)$ & 2.754 & $2.764(1)$ & 3.621 & 2.763 & 2.752 & 3.620 \\
\hline $\mathrm{N} 1 \cdots \mathrm{N} 5$ & 3.609 & $3.574(2)$ & 3.609 & $3.600(1)$ & 2.740 & 3.603 & 3.607 & 2.745 \\
\hline $\mathrm{N} 2 \cdots \mathrm{N} 4$ & 2.756 & $2.751(2)$ & 3.622 & 3.591(1) & 3.621 & 2.766 & 3.622 & 3.620 \\
\hline $\mathrm{N} 2 \cdots \mathrm{N} 6$ & 3.609 & $3.575(2)$ & 2.742 & $2.722(1)$ & 2.740 & 2.599 & 2.743 & 2.746 \\
\hline \multicolumn{9}{|l|}{ Torsion angles } \\
\hline N1-C5-C6-N2 & -179.89 & $178.8(1)$ & 179.85 & $-171.82(9)$ & 180.00 & -37.86 & -33.16 & -34.88 \\
\hline N1-C1-C22-N5 & 179.15 & $-165.7(1)$ & -177.85 & $-172.53(9)$ & -0.26 & 169.62 & 175.26 & -7.14 \\
\hline N2-C10-C11-N6 & 179.15 & $162.3(1)$ & 0.67 & $-21.30(1)$ & 0.26 & 167.33 & -2.24 & -7.50 \\
\hline
\end{tabular}

$\mathrm{CyMe}_{4}$-BTBP conformers were performed at the DFT level by using the B3LYP functional combined with the 6-31G $(\mathrm{d}, \mathrm{p})$ basis set for both the gas phase and solutions (methanol and water) simulated using the Integral Equation Formalism Polarizable Continuum Model $[11,12]$. No imaginary frequency was found for the studied structures confirming that all the conformers were true minima at potential energy surfaces. Relative energies given in Table 3 refer to the Gibbs free energies. The PCM approach was used only to qualitatively check whether the condensed media can significantly influence the conformation or not.

\section{Results and discussion}

\section{Crystal structure studies}

During our studies $\mathrm{CyMe}_{4}$-BTBP was recrystallized from chosen solutions (see experimental part), giving yellow crystals after slow evaporation of solvents at room temperature within a few weeks. It appeared during single crystal X-ray pre-experiment that the same cell parameters were obtained for crystals precipitated from acetonitrile and alcohol solutions, but different from those reported earlier for the $\mathrm{CyMe}_{4}$-BTBP-methanol solvate $(1: 1)$ which crystallized in the $P 2_{1} / n$ space group [1]. Subse-

Table 3. Relative energies $[\mathrm{kJ} / \mathrm{mol}]$ of $\mathrm{CyMe}_{4}$-BTBP conformations calculated in the gas phase and two solutions (the energies are expressed relative to the $t t t$ conformer)

\begin{tabular}{lcrr}
\hline \multicolumn{1}{c}{ Conformer } & Gas phase & $\mathrm{MeOH}$ & $\mathrm{H}_{2} \mathrm{O}$ \\
\hline$t t t$ & 0.00 & 0.00 & 0.00 \\
$t t c$ & 2.82 & -0.40 & 2.33 \\
$c t c$ & 6.34 & 1.70 & 4.76 \\
$t c t$ & 29.15 & 21.32 & 20.72 \\
$t c c$ & 32.27 & 19.89 & 20.00 \\
$c c c$ & 41.66 & 26.19 & 23.62 \\
\hline
\end{tabular}

quent structure measurements found out a new conformer of $\mathrm{CyMe}_{4}$-BTBP which crystallizes without any solvent molecule in the $P \overline{1}$ space group in the $t t c$ conformation (Fig. 1). The arrangement of nitrogen atoms in four aromatic rings in $\mathrm{CyMe}_{4}-\mathrm{BTBP} \cdot \mathrm{MeOH}$ indicated the presence of the $t t t$ conformation [1]. In turn, the crystals obtained from THF solution gave the $\mathrm{CyMe}_{4}$-BTBP-THF solvate $(1: 1)$ with the same space group and conformation as that for its methanol analogue (Fig. 2). For comparison, the C2-BTBP ligand adopts the $c t c$ form in the solid state [1]. The conformation of the tetradentate ligand in both structures presented herein can be described by the three torsion angles formed between aromatic

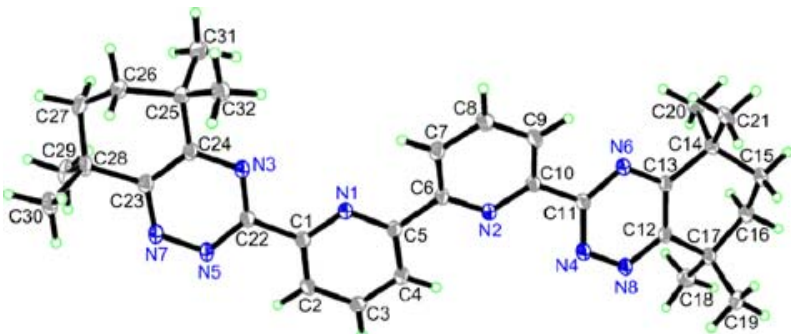

Fig. 1. Molecular structure of $\mathrm{CyMe}_{4}-\mathrm{BTBP}(\mathbf{1})$ with the atom numbering scheme. The non-hydrogen atoms are shown as the $50 \%$ probability displacement ellipsoids.

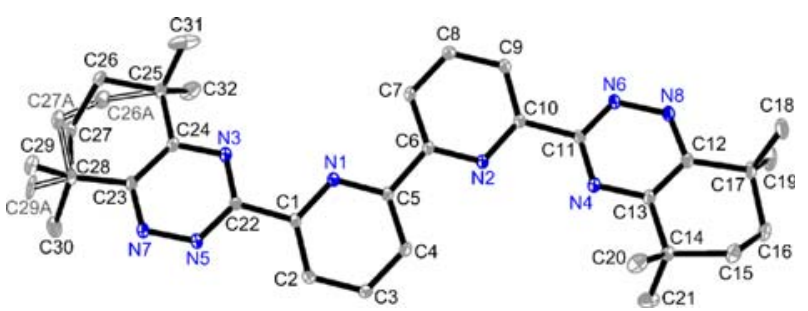

Fig. 2. Molecular structure of $\mathrm{CyMe}_{4}-\mathrm{BTBP}$ as that in its THF solvate (2) with the atom numbering scheme. The modeled disorder in the tetramethylcyclohexane part of ligand is shown. The atoms are plotted with the $25 \%$ probability displacement ellipsoids. Hydrogen atoms are omitted for clarity. 


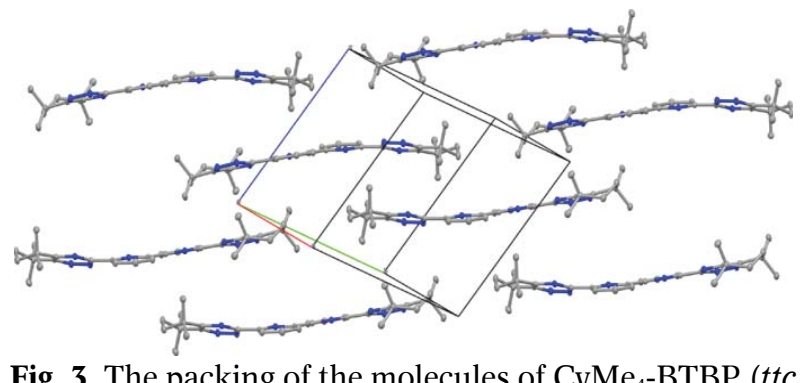

Fig. 3. The packing of the molecules of $\mathrm{CyMe}_{4}$-BTBP (ttc conformer) in the unit cell of $\mathbf{1}$.

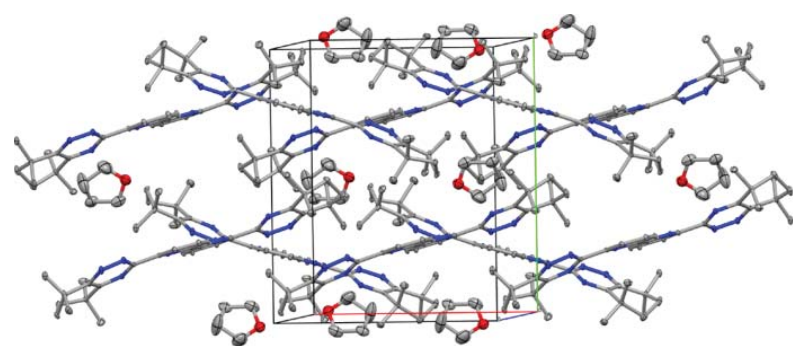

Fig. 4. The packing of the molecules of $\mathrm{CyMe}_{4}-\mathrm{BTBP}(t t t$ conformer) and THF in the unit cell of 2 . The disorder of molecules is omitted for clarity.

rings. For the $t t c$ conformer these torsion angles are equal to $-171.82(9)^{\circ}(\mathrm{N} 1-\mathrm{C} 5-\mathrm{C} 6-\mathrm{N} 2),-171.52(9)^{\circ}$ (N1-C1-C22-N5) and -21.3(1) (N2-C10-C11-N6) (see Table 2). In the case of $t t t$ form, the corresponding torsion angles are 178.8(1), -165.7(1) and $162.3(1)^{\circ}$, respectively. The very similar values were obtained previously for $t t t$ conformation in $\mathrm{CyMe}_{4}-$ -BTBP·MeOH [1]. The packing of the $\mathrm{CyMe}_{4}$-BTBP molecules in structure 1, shown in Fig. 3, involves non-planar molecules of ttc conformer with the shortest $\mathrm{C} \cdots \mathrm{C}$ and $\mathrm{C}-\mathrm{H} \cdots \mathrm{N}$ interatomic distances in the range 3.33-3.58 $\AA(\mathrm{C} 3 \cdots \mathrm{C} 20,3.329(1) \AA, \mathrm{C} 2-$ $-\mathrm{H} 2 \cdots \mathrm{N} 8,3.386(1) \AA, \mathrm{C} 31-\mathrm{H} 31 \mathrm{C} \cdots \mathrm{N} 5$, 3.448(1) $\AA, \mathrm{C} 3-\mathrm{H} 3 \cdots \mathrm{N} 6,3.458(1) \AA, \mathrm{C} 20-\mathrm{H} 20 \mathrm{~A} \cdots \mathrm{N} 6$,

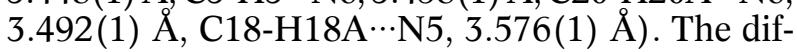
ferent molecular packing can be observed in the case of $\mathrm{CyMe}_{4}$-BTBP.THF solvate (Fig. 4). The crystal structure of $\mathbf{2}$ is stabilized by the presence of the intermolecular hydrogen bonds of 3.290(2) A (C9$-\mathrm{H} 9 \cdots \mathrm{N} 5)$ and $3.370(2) \AA(\mathrm{C} 2-\mathrm{H} 2 \cdots \mathrm{N} 6)$. In turn, the THF molecule forms only a very weak hydrogen-bonding interaction of 3.625(5) $\AA(\mathrm{O} 1 \cdots \mathrm{H} 26 \mathrm{~A}$ -C26) with the neighbouring $\mathrm{CyMe}_{4}-\mathrm{BTBP}$ ligand.

\section{Computational studies}

The geometries of six possible conformers $(t t t, t t c$, $c t c$, $t c t, t c c$ and $c c c$ ) of the CyMe ${ }_{4}$-BTBP ligand in the gas phase and in water and methanol environments were modeled using DFT/IEF-PCM/B3LYP/6$-31 \mathrm{G}(\mathrm{d}, \mathrm{p})$ calculations (Table 3$)$. The previous quantum mechanical calculations were carried out only for the BTBP-type ligand unsubstituted by alkyl groups (C0-BTBP) [1]. The selected bond lengths and distances calculated for the $\mathrm{CyMe}_{4}-\mathrm{BTBP}$ conformers are presented in Table 2. For the $t t t$ and $t t c$ forms, the calculated geometrical parameters are in good agreement with those obtained from the crystal structure determination (Table 2). The Gibbs free energy values determined for all configurations indicate that the most stable in the presented media are three conformers with trans orientation of $\mathrm{N}$ atoms at the bipyridyl part (Table 3). The energies of these forms with a trans central torsion angle are lower than those with the cis angle by ca. $30 \mathrm{~kJ} / \mathrm{mol}$ and $20 \mathrm{~kJ} / \mathrm{mol}$ in the gas phase and in the two solvents, respectively. In the previous calculations performed for the C0-BTBP ligand [1], the analogous energy difference was found to be much smaller in solutions and greater in the gas phase. Nevertheless, one has to bear in mind that the present comparison between Gibbs free energies in the gas phase and in solvents is only a qualitative estimation of the effect of the condensed phase on conformation. Moreover, a more accurate approach requires adopting methodology described in [13].

\section{Conclusions}

The new crystal structures of two conformers of $\mathrm{CyMe}_{4}$-BTBP ligand ( $t t t$ and $t t c$ ) have been obtained experimentally. The ttc conformer crystallized as a pure compound without any solvent molecule while the $t t t$ form was found for the THF solvate. The calculations, carried out at the DFT/B3LYP/6$31 \mathrm{G}(\mathrm{d}, \mathrm{p})$ level of theory, have shown that in chosen media among the six possible conformers of $\mathrm{CyMe}_{4}{ }^{-}$ -BTBP compound the most stable are three forms with trans orientation of $\mathrm{N}$ atoms at the bipyridyl part ( $t t t, t t c$ and $c t c)$. This seems to be in agreement with the experiments where two forms of this ligand have been obtained after crystallization process until now. In turn, the different behavior has been found for its complexes with metals ions for which the $\mathrm{CyMe}_{4}$-BTBP molecule adopts the $c c c$ conformation in order to bind to the metal [3-6].

Acknowledgments. This work has been carried out within the Euratom-Fission collaborative project SACSESS, Contract no. FP7-Fission-2012-323282, and co-financed from the Ministry of Science and Education of Poland, Grant no. 2924/7. PR-EURATOM/2013/2. Computational Grant no. G19-4 from Interdisciplinary Centre for Mathematical and Computational Modelling of University of Warsaw (ICM) is acknowledged for the computer time. This research was also supported by PL-Grid Infrastructure. We thank Dr A. W. Smith from Reading University for the synthesis of the $\mathrm{CyMe}_{4}{ }^{-}$ -BTBP compound.

\section{References}

1. Foreman, M. R. S., Hudson, M. J., Drew, M. G. B., Hill, C., \& Madic, C. (2006). Complexes formed between the quadridentate, heterocyclic molecules 6,6'-bis-(5,6-dialkyl-1,2,4-triazin-3-yl)-2,2'-bipyridine (BTBP) and lanthanides(III): implications for the partitioning of actinides(III) and lanthanides(III). Dalton Trans., 13, 1645-1653. DOI: 10.1039/b511321k.

2. Panak, P., \& Geist, A. (2013). Complexation and extraction of trivalent actinides and lanthanides by tri- 
azinylpyridine N-donor ligands. Chem. Rev., 113(2), 1199-1236. DOI: 10.1021/cr3003399.

3. Whittaker, D. M., Griffiths, T. L., Helliwell, M., Swinburne, A. N., Natrajan, L. S., Lewis, F. W., Harwood, L. M., Parry, S. A., \& Sharrad, C. A. (2013). Lanthanide speciation in potential SANEX and GANEX actinide/lanthanide separations using tetra-N-donor extractants. Inorg. Chem., 52(7), 3429-3444. DOI: 10.1021/ic301599y.

4. Steppert, M., Císařová, I., Fanghänel, T., Geist, A., Lindqvist-Reis, P., Panak, P., Štěpnička, P., Trumm, S., $\&$ Walther, C. (2012). Complexation of europium(III) by bis (dialkyltriazinyl) bipyridines in 1-octanol. Inorg. Chem., 51(1), 591-600. DOI: 10.1021/ic202119x.

5. Lundberg, D., Persson, I., \& Ekberg, C. (2013). Crystal structure of $\left[\mathrm{Eu}\left(\mathrm{CyMe} \mathrm{C}_{4}-\mathrm{BTBP}\right)_{2} \kappa^{2} \mathrm{O}, \mathrm{O}^{\prime}-\left(\mathrm{NO}_{3}\right)\right]$ $\left(\mathrm{NO}_{3}\right)_{2} \cdot n-\mathrm{C}_{8} \mathrm{H}_{17} \mathrm{OH}$ and its structure in 1-octanol solution. Dalton Trans., 42(11), 3767-3770. DOI: 10.1039/C2DT32317F

6. Aneheim, E., Gruner, B., Ekberg, C., Foreman, M. R. S., Hajkova, Z., Lofstrom-Engdahl, E., Drew, M. G. B., \& Hudson, M. J. (2013). Fission product interactions with nitrogen donor ligands used for spent nuclear fuel treatment. Polyhedron, 50(1), 154-163. http:// dx.doi.org/10.1016/j.poly.2012.10.030.

7. Narbutt, J., \& Oziminski, W. P. (2012). Selectivity of bis-triazinyl bipyridine ligands for americium(III) in $\mathrm{Am} / \mathrm{Eu}$ separation by solvent extraction. Part 1. Quantum mechanical study on the structures of BTBP complexes and on the energy of the separation. Dalton Trans., 41(47), 14416-14424. DOI: 10.1039/ C2DT31503C.

8. Sheldrick, G. M. (2008). A short history of SHELX. Acta Crystallogr. Sect. A, 64(1), 112-122. DOI: 10.1107/S0108767307043930.

9. Macrae, C. F., Bruno, I. J., Chisholm, J. A., Edgington, P. R., McCabe, P., Pidcock, E., Rodriguez-Monge, L., Taylor, R., van de Streek, J., \& Wood, P.
A. (2008). Mercury CSD 2.0 - new features for the visualization and investigation of crystal structures. J. Appl. Crystallogr., 41, 466-470. DOI: 10.1107/ S0021889807067908.

10. Frisch, M. J., Trucks, G. W., Schlegel, H. B., Scuseria, G. E., Robb, M. A., Cheeseman, J. R., Scalmani, G., Barone, V., Mennucci, B., Petersson, G. A., Nakatsuji, H., Caricato, M., Li, X., Hratchian, H. P., Izmaylov, A. F., Bloino, J., Zheng, G., Sonnenberg, J. L., Hada, M., Ehara, M., Toyota, K., Fukuda, R., Hasegawa, J., Ishida, M., Nakajima, T., Honda, Y., Kitao, O., Nakai, H., Vreven, T., Montgomery Jr, J. A., Peralta, J. E., Ogliaro, F., Bearpark, M., Heyd, J. J., Brothers, E., Kudin, K. N., Staroverov, V. N., Keith, T., Kobayashi, R., Normand, J., Raghavachari, K., Rendell, A., Burant, J. C., Iyengar, S. S., Tomasi, J., Cossi, M., Rega, N., Millam, J. M., Klene, M., Knox, J. E., Cross, J. B., Bakken, V., Adamo, C., Jaramillo, J., Gomperts, R., Stratmann, R. E., Yazyev, O., Austin, A. J., Cammi, R., Pomelli, C., Ochterski, J. W., Martin, R. L., Morokuma, K., Zakrzewski, V. G., Voth, G. A., Salvador, P., Dannenberg, J. J., Dapprich, S., Daniels, A. D., Farkas, O., Foresman, J. B., Ortiz, J. V., Cioslowski, J., \& Fox, D. J. (2010). Gaussian 09, Revision C.01. [computer software]. Wallingford CT: Gaussian, Inc.

11. Cances, E., Mennucci, B., \& Tomasi, J. (1997). A new integral equation formalism for the polarizable continuum model: Theoretical background and applications to isotropic and anisotropic dielectrics. J. Chem. Phys., 107, 3032-3041. DOI: 10.1063/1.474659.

12. Tomasi, J., Mennucci, B., \& Cammi, R. (2005). Quantum mechanical continuum solvation models. Chem. Rev., 105(8), 2999-3094. DOI: 10.1021/cr9904009.

13. Ho, J., Klamt, A., \& Coote, M. L. (2010). Comment on the correct use of continuum solvent models. I. Phys. Chem. A, 114, 13442-13444. DOI: 10.1021/ jp107136j. 